\title{
The human vagina: normal flora considered as an in situ tissue-associated, adherent biofilm
}

\author{
P A G Domingue, K Sadhu, J W Costerton, K Bartlett, A W Chow
}

\begin{abstract}
Objective-A method that would allow in situ comparison of the degrees of adherence to genital epithelia by the biofilms of the normal flora.

Subjects-Four healthy women.

Setting-Departments of Biological Sciences, University of Calgary, and of Medicine, University of British Columbia.

Methods-In situ, scraped specimens were taken from the vagina and ectocervix before and after vigorous vaginal washes, and colony counts of associated bacteria were compared. In vitro, cells from the vulva, vagina and ectocervix were vortexed, centrifuged and sonicated and remaining associated bacteria quantitated by light microscopy.

Results-Anaerobic lactobacilli were notably tissue-adherent as colony counts of postwash specimens were comparable to those of their paired prewash specimens, but crucially were higher than those of their paired wash specimens ( $p<0.05$, Wilcoxon signed rank test). However, vaginal and ectocervical coagulase-negative staphylococci and ectocervical Lancefield group B streptococci were loosely tissue-adherent, because counts in postwash specimens were lower than those in prewash or wash specimens $(p<0.05$, Wilcoxon signed rank test). In vitro, only
\end{abstract}

Biofilm Research Group, Departments of Biological Sciences and Microbiology and Infectious Diseases, University of Calgary, Calgary T2N 1N4, Alberta, Canada

*P A G Domingue, $\nmid \mathrm{K}$ Sadhu, J W Costerton

Division of Infectious Diseases, Department of Medicine, and Department of Microbiology, University of British Columbia, Vancouver, British Columbia, Canada

K Bartlett, A W Chow

*Current address: Division of Medical Microbiology, Department of Pathology, University of British Columbia Hospital, 2211 Wesbrook Mall, Vancouver, British Columbia, Canada V6T 2B5.

†Current address: Scripps Clinic and Research Foundation, North Torrey Pines Road, La Jolla, CA92037, USA. vulvar scrapings and vaginal postwash specimens showed a significant decrease in associated bacteria after shear stressing ( $p<$ $0 \cdot 05$, Wilcoxon signed rank test).

Conclusions-The normal flora of the female genitalia features both avidly and loosely tissue-adherent bacterial biofilm populations whose adherence can be influenced partly by their location. Our scraping/washing method can contribute to further characterisation of this phenomenon. The superior adherence of anaerobic lactobacilli may reflect a potential in maintaining or restoring normality.

\section{Introduction}

Our perception of the normal, human vaginal flora has evolved considerably from the 1892 concept advanced by Döderlein which was that the flora generally was homogenous and consisted mainly of the Gram-positive Döderlein's bacillus, that is, lactobacillus species. ${ }^{12}$ Improved cultural methods and data interpretation have established that this flora is very diverse, reflecting a dynamic, polymicrobial ecosystem..$^{3-5}$ This can be modulated by host and environmental factors such as the menstrual cycle, contraceptive methods, menstrual products, and sexually transmitted diseases. ${ }^{6-11}$

The properties unique to specific bacteria inevitably influence the balance of this ecosystem. It is accepted now that colonisation by either the normal flora or invading pathogens is an inevitable result of adhesion to mucosal surfaces thereby allowing synergistic and antagonistic associations. ${ }^{12-15}$ As has been pointed out, this tissue tropism is due not only to specific adhesins but can be mediated rapidly by less specific but effective mechanisms. ${ }^{131516}$ Our recent visual study of the human vagina emphasised this. The normal flora were seen to exist as bacterial biofilms that consisted of the same or mixed morphotypes growing as microcolonies within particular ecological niches. It was evident that the cells within such biofilms exhibited a tenacious, intimate association with the genital epithelium as well as with each other, by the aid of their fibrous glycocalyces, that is, exopolysacharride constituents. ${ }^{17}$

In view of this strong adhesive factor, previous 
studies of vaginal flora may have been limited to examining cell-free bacteria or loosely tissueadherent bacteria because of sampling by loops, swabs or washings. ${ }^{18-21}$ In the preliminary study reported here, a novel scraping/washing technique was used to address the question of site-specific or species-specific degrees of adhesion and to quantify the flora of the vulva, vagina and ectocervix through the menstrual cycle of three healthy volunteers. The tissue-associated normal flora was investigated in situ by comparing the composition and bacterial counts of scraped specimens from the vagina and ectocervix before and after vigorous washing. In a fourth volunteer, the avidity of bacterial adherence was estimated by visual quantification of bacteria associated to genital epithelial cells before and after in vitro exposure to considerable shear forces.

(Presented in part at the 89th Annual Meeting of the American Society for Microbiology 1989, and the 39th Annual Meeting of the Canadian Society for Microbiology 1989.)

\section{Materials and methods}

Sampling process. After informed consent, specimens of cells and mucus were collected under direct visualisation by scraping with a sterile tongue depressor placed distal to a vaginal speculum, from four age-matched, healthy women. All were regular tampon users and none received antibiotics prior to or during the course of study. Concurrent sampling showed the absence of sexually transmitted disease and vaginosis. Three locations (vulva, posterior lateral third of the vagina, ectocervix) were sampled through three stages of the menstrual cycle (menstrual, day $3 \pm 2$; midcycle, day $15 \pm 2$; premenstrual, $25 \pm 2$ ) in the first three volunteers and through two menstrual cycles at midcycle (day $15 \pm 2$ ) in the fourth volunteer. In situ sampling was as follows. A first set of scraped specimens (Prewash specimens) was taken from each of three volunteers. Then the vaginal contents were washed out vigorously with $10 \mathrm{ml}$ of phosphate buffered saline, PBS, $\mathrm{pH} 7 \cdot 4$ followed by repeated aspiration and injection twice (Wash specimens). Finally, a second set of scraped specimens (Postwash specimens) was taken from the "mirror sites" of the vaginal and ectocervical prewash locations. For convenience, mirror sites are the identical but opposite sites in a bilaterally symmetrical system. PBS was used because there is no difference between it and pre-reduced Carey Blair medium for the recovery of obligate anaerobes. ${ }^{21}$ Samples from the fourth volunteer were processed in vitro (see Shear Stressing below) to determine further the strength of host tissue-bacteria adhesion and then prepared for light microscopy. Specimens from all volunteers also were aliquoted for electron microscopic assessment. ${ }^{17}$

Bacteriology. Pre- and postwash (scraped) specimens were collected into $10 \mathrm{ml}$ PBS, and wash specimens were processed in an anaerobic cabinet (model 1024; Caltec Ltd, Calgary, Canada) and analysed quantitatively by serial dilution. Final dilutions were plated out in duplicate on to pre-reduced, replicate brain heart infusion (BHI; Difco Laboratories, Detroit, USA) supplemented with $1.5 \%(\mathrm{w} / \mathrm{v})$ proteose peptone number 3 agar (Difco) and on to Rogosa SL agar (Difco). Plates were incubated in air, in $10 \% \mathrm{CO}_{2}$ and anaerobically $\left(80 \% \mathrm{~N}_{2}, 10 \% \mathrm{CO}_{2}\right.$ and $\left.10 \% \mathrm{H}_{2}\right)$ at $37^{\circ} \mathrm{C}$ for a minimum 48 hours before initial examination. They were then re-incubated for a further 48 hours before final examination and identification to species or generic level by standard methods. Bacterial counts were expressed as $\log _{10} \mathrm{cfu} \mathrm{ml}^{-1}$ of diluent. Values were semi-quantitative, as in this pilot study the specimens were not weighed, but our procedure was still highly sensitive (lower limit of detection, $10^{2} \mathrm{cfu} \mathrm{ml}^{-1}$ ) and reproducible (correlation coefficient, 0.994 by duplicate sampling in three subjects).

Shear stressing prior to microscopy. This was studied in the fourth volunteer with the intention of providing more rigorous evidence of the strength of adhesion of the normal flora to host tissue. Prewash, wash and postwash specimens from all sites were vortexed (medium setting, $30 \mathrm{~s}$; Vortex-Genie, Scientific Industries, New York, USA) and allowed to settle on the bench for 15 minutes. They were then centrifuged ( $300 \mathrm{rpm}, 4^{\circ} \mathrm{C}, 15$ minutes; Centra $7 \mathrm{C}$, IEC, Needham Heights, USA). The resultant pellet was resuspended in $10 \mathrm{ml}$ of PBS, and sonicated (50/ $60 \mathrm{~Hz}, 1.0$ A, 5 minutes; Model B-220, Bransonic, Shelton, USA). Specimens were allowed to settle out as above before sonication was repeated. Finally, after settlement, the sediments were processed for light microscopy.

Light microscopy. Some sediments were examined by phase contrast while others were examined by an Alcian Blue/Safranin double stain. ${ }^{22}$ Bacteria adherent to a minimum 20 viable, squamous epithelial cells were counted. Untreated controls from the same specimen served as controls.

Statistical analyses. Bacterial counts were categorised according to anatomical site (vulva, vagina and ectocervix) and group comparisons were analysed using non-parametric techniques. Owing to the relatively small sample size, data from all cycle days were pooled for each volunteer at each anatomical site (that is, each data set for a specific site contained nine samples from three volunteers, each with three specimens from different stages of the menstrual cycle). For comparison of bacterial counts between groups, paired data (for example, postwash versus prewash or postwash versus wash) for each volunteer and anatomical site were analysed by the one-tailed Wilcoxon signed rank test. Genital flora were considered to be avidly tissue-adherent if bacterial 
counts in the postwash specimens were comparable to those in the paired prewash specimens but significantly greater $(p<0.05)$ than those of wash specimens. Conversely, genital flora were considered to be loosely tissue-adherent if the postwash counts were significantly lower than those in either prewash or wash specimens. The relative resistance of tissueassociated flora to dislodgement by the in vitro shear forces was assessed by comparison of mean counts of cell-associated bacteria between treated and untreated samples using the one-tailed Wilcoxon rank sum test. Differences in viable or total (microscopy) counts between sites were analysed by the two-tailed Wilcoxon signed rank test for paired data, or the twotailed Wilcoxon rank sum test for independent groups, respectively. Finally, the association of viable counts between anatomical sites, and between prewash, postwash, and wash specimens was examined by the Spearman rank correlation test.

\section{Results}

This was intended as a pilot study to test feasibility and therefore only a small sample number was used. Accordingly, no statistical comparison in the qualitative or quantitative differences of isolates was determined between different stages of the menstrual cycle. Only predominant bacteria feature unless otherwise stated.
Site-specific bacteriology. The predominant, normal flora of the vulva, vagina and ectocervix in prewash specimens obtained during the menstrual cycle from the three volunteers are summarised in table 1 . Strictly anaerobic lactobacilli and Lancefield group D streptococci were the predominant isolates from all volunteers from all sites and cycle days. Other bacterial groups were isolated variably from different days of the cycle. In general, facultative bacteria were more predominant in menstrual samples, while strict anaerobes were more predominant in premenstrual samples. The data from different cycle days of the same volunteer were then pooled to examine any quantitative differences in flora at various anatomical sites (table 1). Little difference between the vaginal and paired ectocervical samples was observed $(p>$ 0.05 , two-tailed Wilcoxon signed rank test). However, counts of group D streptococci from the vulva were significantly higher than those of paired specimens from the ectocervix $(p<0.05$, table 1$)$. In general, there was good correlation between the recovery of specific isolates at the three sites sampled, particularly between vaginal and ectocervical isolates ( $p<0.05$, Spearman rank correlation, for all major bacterial groups except the anaerobic lactobacilli and group D streptococci, data not shown). There was less correlation between vulvar and vaginal isolates but only for facultative lactobacilli and pepto-

Table 1 The predominant microflora $\left(\log _{10} c f u \mathrm{ml}^{-1}\right.$; mean (SEM)) in prewash specimens from three healthy volunteers during the menstrual cycle

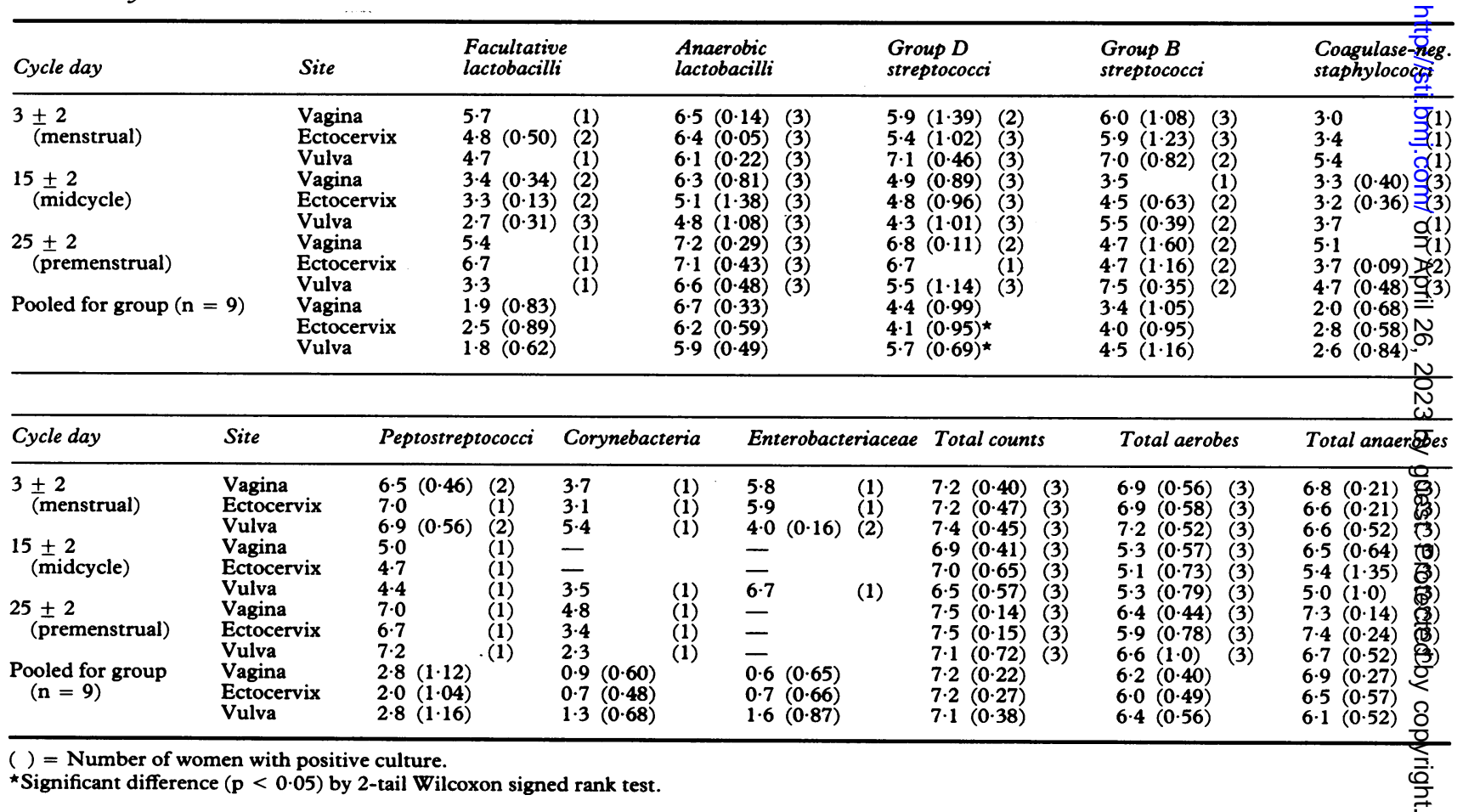


Table 2 Paired comparison of bacterial counts $\left(\log _{10} c f u \mathrm{ml}^{-1}\right.$; mean (SEM)) in prewash, postwash and wash specimens from three healthy volunteers on three separate cycle days $(n=9)$

\begin{tabular}{|c|c|c|c|c|c|c|c|c|c|c|}
\hline \multirow[b]{3}{*}{$\begin{array}{l}\text { Predominant isolate } \\
\text { Facult. lactobacilli } \\
\text { Anaer. lactobacilli } \\
\text { Group D streptococci } \\
\text { Group B streptococci } \\
\text { Coag. neg. staphylococci } \\
\text { Peptostreptococci } \\
\text { Corynebacteria } \\
\text { Enterobacteriaceae } \\
\text { Total counts } \\
\text { Total facultatives } \\
\text { Total anaerobes }\end{array}$} & \multicolumn{4}{|c|}{ Vagina } & \multicolumn{4}{|c|}{ Cervix } & \multirow{2}{*}{\multicolumn{2}{|c|}{$\begin{array}{l}\text { Cervico-vaginal } \\
\text { wash }\end{array}$}} \\
\hline & \multicolumn{2}{|c|}{ Prewash } & \multicolumn{2}{|c|}{ Postwash } & \multicolumn{2}{|c|}{ Prewash } & \multicolumn{2}{|c|}{ Postwash } & & \\
\hline & $\begin{array}{l}1 \cdot 9 \\
6 \cdot 7 \\
4 \cdot 4 \\
3 \cdot 4 \\
2 \cdot 0 \\
2 \cdot 8 \\
0 \cdot 9 \\
0 \cdot 6 \\
7 \cdot 2 \\
6 \cdot 2 \\
6 \cdot 9\end{array}$ & $\begin{array}{l}(0.83) \\
(0.33) \\
(0.99) \\
(1.05) \\
(0.68) \\
(1.12) \\
(0.60) \\
(0.65) \\
(0.22) \\
(0.40) \\
(0.27)\end{array}$ & $\begin{array}{l}2 \cdot 1 \\
6 \cdot 6 \\
4.9 \\
3 \cdot 0 \\
2 \cdot 1 \\
2 \cdot 6 \\
0 \cdot 8 \\
0.8 \\
7 \cdot 2 \\
6 \cdot 1 \\
6.8\end{array}$ & $\begin{array}{l}(0.89) \\
(0.38)^{\star} \\
(0.90) \\
(0.88) \\
(0.71) \\
(1.08) \dagger \\
(0.57) \\
(0.78) \\
(0.28) \\
(0.47) \\
(0.31)^{\star}\end{array}$ & $\begin{array}{l}2 \cdot 5 \\
6 \cdot 2 \\
4 \cdot 1 \\
4 \cdot 0 \\
2 \cdot 8 \\
2 \cdot 0 \\
0 \cdot 7 \\
0 \cdot 7 \\
7 \cdot 2 \\
6 \cdot 0 \\
6 \cdot 5\end{array}$ & $\begin{array}{l}(0.88) \\
(0.59) \\
(0.95) \\
(0.95) \\
(0.58) \\
(1.04) \\
(0.49) \\
(0.66) \\
(0.27) \\
(0.49) \\
(0.57)\end{array}$ & $\begin{array}{l}1 \cdot 5 \\
6 \cdot 2 \\
4 \cdot 3 \\
1 \cdot 4 \\
1 \cdot 8 \\
1 \cdot 9 \\
0 \cdot 7 \\
0 \cdot 8 \\
6 \cdot 7 \\
5 \cdot 9 \\
6 \cdot 3\end{array}$ & $\begin{array}{l}(0.81) \\
(0.34)^{\star} \\
(1.01) \\
(0.73) \dagger \\
(0.47) \dagger \\
(1.01) \\
(0.50) \\
(0.79) \\
(0.36) \dagger \\
(0.47) \\
(0.35)^{\star}\end{array}$ & $\begin{array}{l}2 \cdot 7 \\
5 \cdot 2 \\
4 \cdot 2 \\
4 \cdot 3 \\
4 \cdot 3 \\
1 \cdot 9 \\
0 \cdot 3 \\
1 \cdot 6 \\
6 \cdot 9 \\
6 \cdot 3 \\
5 \cdot 5\end{array}$ & $\begin{array}{l}(1.12) \\
(0.74) \\
(1.06) \\
(1.08) \\
(0.68) \\
(0.94) \\
(0.31) \\
(1.04) \\
(0.24) \\
(0.52) \\
(0.67)\end{array}$ \\
\hline
\end{tabular}

^Avidly tissue-adherent (counts significantly higher than in paired wash specimens; $p<0.05,1$-tail Wilcoxon signed rank test).

†Loosely tissue-adherent (counts significantly lower than in paired prewash or wash specimens; $\mathrm{p}<0.05,1-t$ ail $W$ ilcoxon signed rank test).

Table 3 Effect of mechanical shearing on counts of tissue-associated bacteria (no. per epithelial cell, mean (SEM)) from mid-cycle specimens of volunteer one

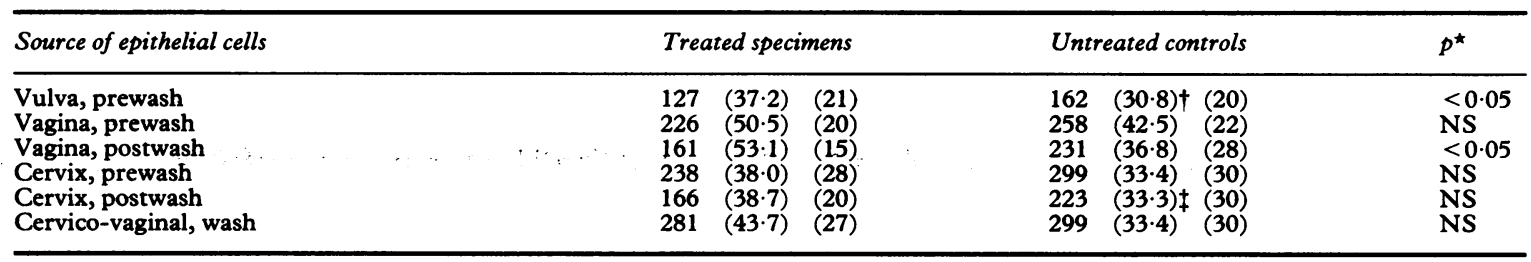

^1-tail Wilcoxon rank sum test.

tLower than untreated cervical prewash; $p<0.05,2$-tail Wilcoxon rank sum test.

$\ddagger$ Lower than untreated cervical prewash and wash; $p<0.05$, Wilcoxon rank sum test.

streptococci (data not shown), and also between vulvar and ectocervical isolates for group D and B streptococci and peptostreptococci (data not shown).

The degree of tissue adherence of the predominant in situ vaginal and ectocervical flora was examined by comparing bacterial counts between postwash and paired prewash or wash specimens from the volunteers (table 2). Anaerobic lactobacilli from both the vagina and ectocervix were avidly tissue-adherent as counts from postwash specimens at these sites were comparable to those of paired prewash specimens but significantly higher than those of wash specimens $(\mathrm{p}<0.05$, one-tailed Wilcoxon signed rank test). In contrast, coagulase-negative staphylococci from both the vagina and ectocervix, and group B streptococci from the ectocervix were loosely tissue-adherent as bacterial counts in postwash specimens were significantly lower than those of either paired prewash or wash specimens $(p<0.05)$. Notably, the total counts in postwash specimens from the ectocervix were lower than in paired prewash specimens $(p<0.05)$. Light microscopy of epithelial cells. The mean numbers of bacteria associated with viable epithelial cells recovered from the three sites in the fourth volunteer, prior to and after shearing are shown in table 3 and the figure. The stresses applied caused a significant reduction in tissue-associated bacteria only for vulvar specimens and vaginal postwash specimens $(p<0.05$, one-tailed Wilcoxon rank sum test). There was no statistically significant difference between treated and untreated specimens for vaginal or ectocervical prewash specimens, nor from ectocervical postwash or vaginal wash specimens. Similar to the observation from quantitative bacteriology, the mean counts of cell-associated bacteria in postwash specimens from the ectocervix were also significantly lower than those from paired ectocervical prewash or wash specimens $(p<0.05$, one-tailed Wilcoxon rank sum test). Finally, mean counts of cell-associated bacteria in untreated specimens from the vulva were significantly lower than paired ectocervical prewash specimens ( $p<$ 0.05 , two-tailed Wilcoxon rank sum test).

\section{Discussion}

Our aim was to use a pilot study to develop experimental methods that could help characterise the in situ tissue-associated normal flora of the lower female 


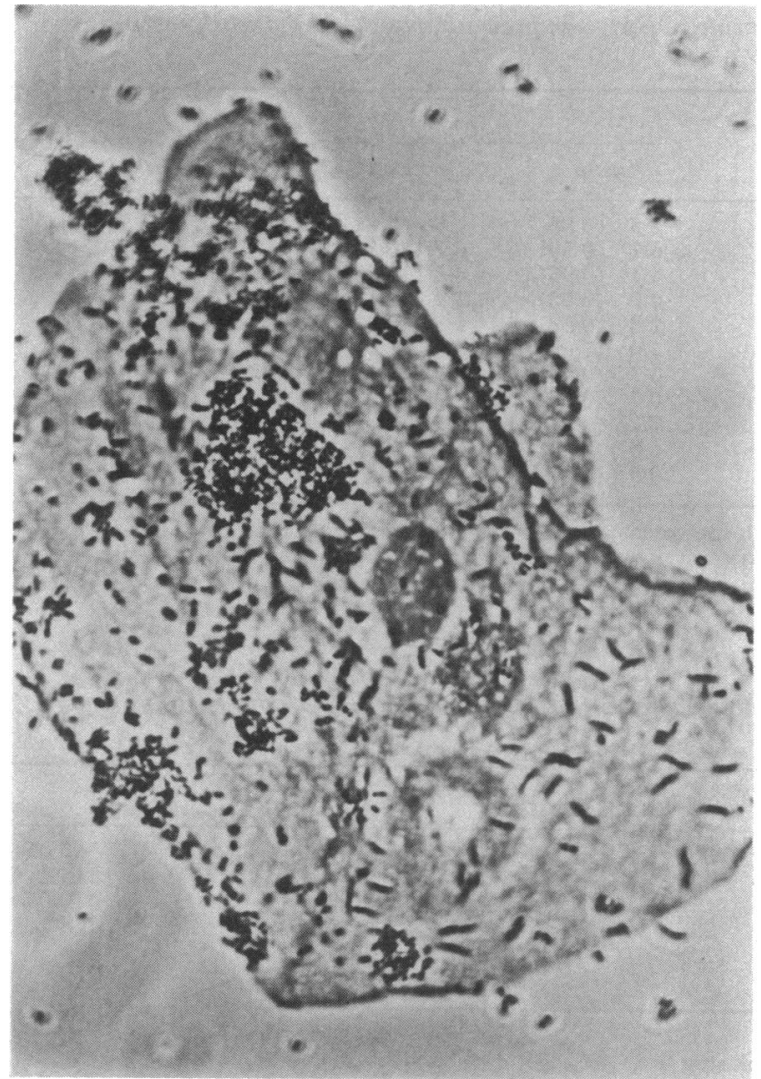

Figure Phase contrast micrographs of genital epithelial cells (volunteer 4) subjected to vortex mixing (medium setting, $30 \mathrm{~s})$, centrifugation ( $300 \mathrm{rpm}, 15 \mathrm{~min}$ ), and low output sonication ( $50 / 60 \mathrm{~Hz}, 1.0 \mathrm{~A}, 5 \mathrm{~min})$. These epithelial cells retained substantial bacteria despite exposure to strong shear forces.

genital tract. The results clearly reveal the presence of both avidly tissue-adherent (for example, anaerobic lactobacilli) and loosely tissue-adherent (for example, coagulase-negative staphylococci and group B streptococci) bacterial populations in the normal flora of the human vagina and ectocervix. These results from quantitative cultures are supported both by direct visualisation under light microscopy reported here, and by our morphological observations using transmission electron microscopy reported previously. ${ }^{17}$ The present study is also unique in that despite the small sample size of volunteers studied, we were able to observe statistically significant differences in the flora by comparing paired specimens of the same individual at the same sampling times from three separate stages of the menstrual cycle, thus minimising potentially confounding variables by having each individual essentially serving as her own control. Although our samples were not weighed before analysis, and it is theoretically possible that any differences observed could be due to sample variability rather than actual change in bacterial counts, this is unlikely due to: (a) demonstrated reproducibility of the quantitative method by replicate sampling; $(b)$ consistency in the direction of change in the prewash, postwash and wash specimens for all isolates; and (c) validation of the quantitative data by direct visualisation under light and electron microscopy. The data presented here provide strong evidence of the need for quantitative sampling methods that take into account the in situ tissue-associated bacterial populations in studies of the normal flora of the human female genital tract. Conventional culture techniques which use mucosal loops or swabs, or vaginal washings are likely to yield data that is highly skewed towards the loosely tissueadherent populations or towards cell-free bacteria present in mucus secretions or associated with sloughed and non-viable epithelial cells. Additionally, vaginal secretions are a mixture of fluids from various sites, such as the cervix and glands, the cervical mucosa and the vagina itself, so the pattern of the flora that is typical of each site may become blurred by such sampling methods. We believe that our scraping/washing technique, used in conjunction with light or electron microscopy, has provided additional information not available from conventional studies of the cervico-vaginal flora.

There have been a multitude of previous studies to examine the qualitative and quantitative flora of the normal human vagina, cervix and vulva. ${ }^{4} 7^{78-20}$ Evaluation of such studies and interpretation of data have been fraught with difficulty, mainly because of a lack of standardisation of sampling methods and culture techniques, the non-normal distribution of the indigenous flora due to their attachment to heterogenous epithelial cell populations, and confounding host factors such as age, contraceptive practices, stage of the menstrual cycle, usage of menstrual products, and existence of underlying conditions. Enumeration of bacteria adherent to epithelial cells is also not straightforward because of the technical considerations. ${ }^{23-25}$ We concur with Rosenstein et $a l,{ }^{25}$ that assessment of the tissueassociated flora by mean bacterial counts per cell can be inaccurate due to non-normal distributions; and with Bibel et al, ${ }^{23}$ that a more reliable measurement of adherence may be the quantitation of bacterial counts per unit surface area of the cell, that is, the density of bacterial adherence. Our microscopic studies indicate that significantly fewer bacteria were associated with epithelial cells from the vulva compared to paired specimens from the ectocervix in the same individual ( $p<0.05$, Wilcoxon rank sum test, 2 tail; table 3). Furthermore, bacteria adherent to vaginal and ectocervical cells resisted shear forces more effectively than bacteria adherent to vulval epithelial cells $(p<0.05)$. These data support the observations by Bibel et $a l,{ }^{23}$ that the complex 
ecology of the vulva is also strongly influenced by factors that relate to microbial adherence.

There is still considerable debate as to the nature and underlying mechanism which account for the cyclic variation of the normal vaginal flora associated with menses. ${ }^{5-7}$ Our quantitative studies reported here and previously, ${ }^{626}$ suggest that while the overall bacterial counts remain relatively constant throughout the menstrual cycle, the proportion of obligate anaerobes increases while that of facultative anaerobes decreases in premenstrual samples compared to menstrual or midcycle specimens in the same individuals. Our finding that anaerobic lactobacilli, as well as group D and group B streptococci and peptostreptococci, were the predominant cervico-vaginal isolates throughout the menstrual cycle are in agreement with several recent reports by other investigators. ${ }^{259192027}$ Our observation of the high degree of in situ tissue-adherence by anaerobic lactobacilli is also consistent with in vitro studies of adherence by lactobacilli to human vaginal epithelial cells. $^{2428}$ This avidity of tissue-adherence may account for the putative, protective role of lactobacilli generally, especially the anaerobic lactobacilli in our opinion, in host resistance to genital infections. ${ }^{16}$ Closer attention to the phenomenon of in situ tissue-associated biofilms may lead to a better understanding not only of the ecological potential of these indigenous bacteria in resistance to colonisation and infection by pathogens, but also to the topology of the complex ecosystems of this tract. ${ }^{1315162427}$ We believe that our technique will help in this regard.

This work was supported in part by a grant from the Medical Research Council of Canada (MT-7630). KS was the recipient of a grant from the Alberta Heritage Foundation for Medical Research.

\section{Address correspondence to Professor Costerton.}

1 Larsen B, Galask RP. Vaginal microbial flora: practical and theoretical relevance. Obstet Gynecol 1980;55(Suppl): 1005-135.

2 Stahl CE, Hill GB. Microflora of the female genital tract. In: Galask RP, Larsen B, eds. Infectious Diseases in the Female Patient. New York: Springer-Verlag, 1986:16-42.

3 Barlett JG, Onderdonk AB, Drude E, et al. Quantitative bacteriology of the vaginal flora. J Infect Dis 1977;136:271-7.

4 Levison ME, Corman LC, Carrington ER, Kaye D. Quantitative microflora of the vagina. Am J Obstet Gynecol 1977; 127:80-5.

5 Wilks $M$, Thin RN, Tabaqchali S. Quantitative methods for studies on vaginal flora. J Med Microbiol 1982;15:141-7.

6 Chow AW, Bartlett $\mathrm{KH}$. Sequential assessment of vaginal microflora in healthy women randomly assigned to tampon or napkin use. Rev Infect Dis 1989;8:s68-s74.

7 Johnson SR, Petzold CR, Galask RP. Qualitative and quantitative changes of the vaginal microbial flora during the menstrual cycle. Am J Reprod Immunol 1985;9:1-5.

8 Larsen B, Galask RP. Vaginal microbial flora: composition and influences of host physiology. Ann Int Med 1982;96:926-30.

9 Onderdonk AB, Zamarchi GR, Rodriguez ML, Hirsch ML, Munoz A, Kass EH. Quantitative assessment of vaginal microflora during use of tampons of various compositions. Appl Environ Microbiol 1987;53:2774-8.

10 Onderdonk AB, Zamarchi GR, Rodriguez ML, Hirsch ML, Munoz A, Kass EH. Qualitative assessment of vaginal microflora during use of tampons of various composition. Appl Environ Microbiol 1987;53:2779-84.

11 Wilks M, Thin RN, Tabaqchali S. Quantitative bacteriology of the vaginal flora in genital disease. J Med Microbiol 1984; 18:217-31.

12 Bibel DJ, Aly R, Bayles C, Strauss WG, Shinefield HR, Maibach HI. Competitive adherence as a mechanism of bacterial interference. Can J Microbiol 1983;29:700-3.

13 Costerton JW, Cheng K-J, Geesey GG, et al. Bacterial biofilms in nature and disease. Ann Rev Microbiol 1987;41:435-64.

14 Cheng K-J, Irvin RT, Costerton JW. Autochthonous and pathogenic colonization of animal tissues by bacteria. Can J Microbiol 1981;47:461-90.

15 Reid G, Sobel JD. Bacterial adherence in the pathogenesis of urinary tract infection. Rev Infect Dis 1987;9:470-87.

16 Reid G, Bruce AW, McGroarty JA, Cheng K-J, Costerton JW. Is there a role for lactobacilli in prevention of urogenital and intestinal infections? Clin Microbiol Rev 1990;3:355.

17 Sadhu K, Domingue PAG, Chow AW, Nelligan J, Bartlett K, Costerton JW. A morphological study of the in situ tissueassociated autochthonous microflora of the human vagina. Microb Ecol Health Dis 1989;2:99-106.

18 Bartlett JG, Moon NE, Goldstein PR, Goren B, Onderdonk AB, Polk CF. Cervical and vaginal bacterial flora: ecologic niches in the female lower genital tract. Am J Obstet Gynecol 1978;130: 658-61.

19 Gibbs RS. Microbiology of the female genital tract. Am J Obstet Gynecol 1987;156:491-95.

20 Masfari AN, Duerden BI, Kinghorn GR. Quantitative studies of vaginal bacteria. Genitourin Med 1986;62:256-63.

21 Onderdonk AB, Zamarchi GR, Walsh JA, Mellor RD, Munoz $\mathrm{A}, \mathrm{Kass} \mathrm{EH}$. Methods for quantitative and qualitative evaluation of vaginal microflora during menstruation. Appl Environ Microbiol 1986;51:333-9.

22 Reid G, Brooks HJL. The use of double staining techniques for investigating bacterial attachment to mucopolysaccharidelocated epithelial cells. Stain Technol 1982;57:5-9.

23 Bibel DJ, Aly R, Lahti L, Shinefield HR, Maibach HI. Microbial adherence to vulvar epithelial cells. J Med Microbiol 1987; 23:75-82.

24 Mardh P-A, Westrom L. Adherence of bacteria to vaginal epithelial cells. Infect Immun 1976;13:661-6.

25 Rosenstein IJ, Grady D, Hamilton-Miller JMT, Brumfitt W. Relationship between adhesion of $E$. coli to uro-epithelial cells and the pathogenesis of urinary infection: problems in methodology and analysis. J Med Microbiol 1985;20:335-44.

26 Chow AW, Percival-Smith R, Bartlett KH, Goldring AM, Morrison BJ. Vaginal colonization with Escherichia coli in healthy women. Determination of relative risks by quantitative culture and multivariate statistical analysis. Am J Obstet Gynecol 1986;154:120-6.

27 Martius J, Krohn MA, Hillier SL, Stamm WE, Holmes KK, Eschenbach DA. Relationships of vaginal Lactobacillus species, cervical chlamydia trachomatis, and bacterial vaginosis to preterm birth. Obstet Gynecol 1988;71:89-95.

28 Sobel JD, Schneider J, Kaye D, Levison ME. Adherence of bacteria to vaginal epithelial cells at various times in the menstrual cycle. Infect Immun 1981;32:194-7.

Accepted for publication 18 March 1991 